\title{
Making of a Great Filipino Nurse Educator
}

\author{
Jesusa V. Gutierrez ${ }^{1,2}$ (1) \\ ${ }^{1}$ St. Paul University Manila, Manila, Philippines \\ ${ }^{2}$ Nursing Department, Faculty of Applied Medical Science, University of Tabuk, Tabuk, KSA \\ Email: jgutierrez@ut.edu.sa
}

How to cite this paper: Gutierrez, J.V. (2020) Making of a Great Filipino Nurse Educator. Open Journal of Nursing, 10, 563-594.

https://doi.org/10.4236/ojn.2020.105039

Received: April 1, 2020

Accepted: May 26, 2020

Published: May 29, 2020

Copyright $\odot 2020$ by author(s) and Scientific Research Publishing Inc. This work is licensed under the Creative Commons Attribution International License (CC BY 4.0).

http://creativecommons.org/licenses/by/4.0/ (c) (i) Open Access

\begin{abstract}
The research study aimed to identify the defining characteristics of a great Filipino nurse educator which have provided input in developing a theoretical model of a great Filipino nurse educator. This research is a qualitative study which employed a grounded theory methodology toward theory development. The following findings generated 26 categories and 9 themes from the responses of 53 nursing students and professionals. Findings revealed that the great Filipino nurse educator is defined to be a world-class (World-Klas) nurse educator who is highly qualified (Kwalipikado) from having education, experience, physical and mental fitness and being a lifelong learner. $\mathrm{He}$ is competent (Natatanging Kakayahan) in teaching, leadership and managerial roles, and engages in research and accreditation. He possesses caring ( $\mathrm{Ma}$ pagmahal) behaviors that are shown through communication, passion, compassion, commitment, inspiration and empowerment, transcendence, nurturing and belief in his student's capabilities. She is equipped with well-rounded personality (Mabuting Pagkatao) comprising of positive traits, versatility, resilience and sense of humor. She is spiritual (Maka-Diyos), patriotic (Maka-Bayan), a role-model (Idolo) and catalyst agent (Tagasulong ng Pagbaba$g o$ ). The road to greatness of a Filipino nurse educator is all attuned with the strongest core of being spiritual and patriotic that makes it very Filipino which demarcates a great Filipino nurse educator from what is not. Each characteristic is significant because all are important in describing what a great Filipino nurse educator is. One characteristic cannot be absent nor removed for it will not decipher the puzzle of what completes the defining characteristics of a great Filipino nurse educator. Total greatness is not an end product; it is an ongoing, deliberative process. Teacher's greatness is a lifelong pursuit. Greatness is the result of many factors.
\end{abstract}

\section{Keywords}

Nurse Educator, Greatness, Filipino Nurse, Spiritual 


\section{Introduction}

Teaching is a rich and rewarding pursuit for nurses looking to share their clinical expertise with those entering the profession or nurses returning to practice with advanced preparation. As an educator, one can model professional values and skills, and ultimately influence the quality of care provided by future nurses. It is said that ... "he who is a great influence was also influenced, for you cannot give what you don't have." In years of teaching, one educator can be agitated, touched, and inspired and crossed paths with people who are extraordinary exceptional in their craft possessing gazillion of altruistic traits-her great teachers. While doing great and good deeds apparently is a cycle from having experienced it, so is teaching. Being an educator is not by circumstance but by choice.

In a powerful grounded theory research an effective teacher was introduced as an expert in all four areas of teaching namely subject matter, classroom management, instruction and diagnostic in teaching. It was further emphasized that the effective teacher has diagnostic expertise, which refers to the ability of the teacher to know both class and individual needs and goals, abilities, achievement levels, motives, personal attributes, and emotions which influence instruction and learning [1].

Indeed, the only direct and daily observers of a teacher's classroom teaching performance are the students themselves. They are the living witnesses of the extent of the teacher's influence in their lives. The students' feedback and individual successes become the teacher's trophy of his own success and the fuel to continue the passion of teaching.

The readings made by the researcher showed that the concept of a great nurse educator appears to have attracted less attention. Surveys of the literature showed no research that was conducted to provide theoretical understanding of a great nurse educator. A check on Google Scholar, Medline Plus, Cinahl, Science Direct, PubMed, and Microsoft Academic Search showed no results about a great nurse leader. However, several, if not many literatures have alluded to the fact that success of many nurses in the field has been affected or is results of the influences of the so-called great nurse educator.

Nurses constitute an important element of the medical team. The quality of the clinical practice of student nurses is dependent primarily on the expertise and supervisory skills of their clinical instructors. The impact of the personality, interpersonal relationship and the ability to draw trust and confidence by the clinical instructor from the staff nurses, patients and the patients' relatives will pave the way for the students under her supervision to gain more access and more hands-on experiences [2].

Nurse educators play a pivotal role in strengthening the workforce, serving as role models, and providing the leadership needed to implement evidence-based practice and improve patient outcomes [3]. The most important quality of being a good nurse is having compassion. A nurse with compassion is one who truly cares about her patient's well-being and outcome [4]. 
To be a successful nurse leader in any field, a nurse educator must be able to possess certain competencies. The health care environments today challenge the skills of even the best nursing leaders. Whether it is issues of retaining staff, concern about patient safety, meeting the budget or complying with regulatory rules, more demands are being made of professionals in nursing leadership positions. Nurse leaders identified personal mastery, interpersonal effectiveness, financial management, human resource management, caring and systems thinking as critical leadership competencies for today's nursing managers [5].

The foregoing discussion, the lack of a clear picture of a "great nurse educator", and the experiences of the researcher brought about the desire to conduct this study to describe a great Filipino nurse educator and develop a theoretical understanding of what or who he/she is from the varied point of views of different stakeholders.

\subsection{Background of the Study}

Nurse educator is a trained nurse that educates and trains future nurses. It is a profession that involves teaching nursing students nursing theories. A nurse educator should have the skills and advanced nursing practices and be able to reach and demonstrate to the students. The nurse educator should possess the real passion for excellence in the nursing field. The first responsibility of a nurse educator is to teach. These professionals often work in both classrooms and clinical settings, teaching new nursing student courses as well as continuing education courses. In order to perform their jobs well, they must have excellent leadership skills and an in-depth knowledge of their fields. Most nurse educators will also act as role models and advisers, helping students along their journeys toward becoming successful nurses [6].

A mediocre teacher tells, the good teacher explains; the superior teacher demonstrates, but the great teacher inspires. Becoming a teacher in higher education is due to the passion and motivation experienced by a nurse educator from lecturers during her nurse education [7]. To be a successful academic in nursing education, two core ingredients are required: practice experience and teaching skills. This enables new academics to facilitate development, identify professional boundaries and support students to acquire the skills necessary to become competent in practice. Nurse education requires a teacher to be dynamic, supportive, caring, empathetic, challenging and knowledgeable. Therefore, new teachers in higher education need support and guidance so they can reflect and review their practice to see how they can develop and improve [8]. This is supported by Hunt who explained that academic nurse educators must possess the required clinical and educational competencies. Furthermore, he must possess the types of educator role, educational requirements and experience, major responsibilities and key attributes, teaching, service and scholarship, and the rank, tenure and academic freedom [7]. The identified top 5 qualities that make educators successful in nursing classes which include the following: passion, pa- 
tience, socially approachable, reflection and dedication. These five qualities, she said, would make a good instructor stand out [9].

In the study entitled, "My journey of becoming a nurse", findings revealed the importance of the nurse independence from all forces such as politicians, legislators, administrators and other non-nursing professionals. Nurses must be more active in the political arena to enhance the nurses' voice and clout. Nurses as primary and essential care givers must advocate for quality patient care for all people. Nurses should be prepared at the highest educational level because technology is forever changing, people are getting sicker and evidence-based information is focusing on a broader array of practice issues, education and prevention [10].

What qualifies an effective teacher? In a powerful grounded theory research conducted, an effective teacher is an expert in all four areas of teaching namely subject matter, classroom management, instruction and diagnostic in teaching. $\mathrm{He}$ is someone with a post-graduate degree holder in a field of specialization, who possess the personal attributes, virtues and teaching methods that nurture a favorable teacher-student relationship. He draws inspiration from both within and outside the school. She is cheerful, willing and motivated person always in the pursuit of continued professional growth. The four areas of expertise of the outstanding teacher, she said that the teacher must have subject matter expertise, which means that the teacher has a mastery of content-specific knowledge and the organization of this knowledge for effective instruction. The teacher likewise, must possess classroom management expertise, which means that the teacher maintains a high level of on-task students' classroom behavior, which prevents or eliminates learning disruptions, while it creates an environment conducive to learning. Likewise the outstanding teacher has instructional expertise, which means that the teacher has both implicit and explicit knowledge on various teaching strategies and methods to attain predefined instructional objectives. Moreover, the effective teacher has diagnostic expertise, which refers to the ability of the teacher to know both class and individual needs and goals, abilities, achievement levels, motives, personal attributes, and emotions which influence instruction and learning [1].

The nursing field has a rich history, from Florence Nightingale setting standards for healthy nursing environments to Patricia Benner showing nurses everywhere how to rate their experience level and understand their scope of practice. World Health Organization identified 49 core competencies of nurse educators. There are thirteen domains and each domain consists of various competencies. The domains include ethical and legal principles of nursing education, nursing practice, educational theory and conceptual learning, teaching and learning in the clinical area, integration of theory and practice, assessment and evaluation of students and course/program outcomes, educational program development and evaluation, program management and administration, leadership and advocacy, effective communication, collaboration and inter-disciplinarily, 
research and professionalism [11].

There is an article that dramatizes the presentation of the metamorphosis of a nurse to becoming a nurse educator by using butterfly from the egg phase, to the caterpillar phase, to the pupa phase and the butterfly phase that if butterfly reproduce, nurses on the other hand, replicate. An excellent nurse produces another great one and inspiring others to be a great nurse [12]. This is congruent with another study who said that great nurses' journey starts at keeping in mind is where we started which will give a base point to begin with and use to keep us on track [13].

A research regarding clinical experience of nurse educator which examined the effects of hospital contextual factors and individual nurse education and experience on clinical nursing expertise in a cross-sectional analysis of data from 8611 registered nurses. In a generalized ordered logistic regression analysis, the composition of the hospital staff, particularly the proportion of nurses with at least a bachelor of science in nursing degree, was associated with significantly greater odds of a nurse reporting a more advanced expertise level. Their findings suggest that, controlling for individual characteristics, the hospital context significantly influences clinical nursing expertise [14].

The literature and studies reviewed and cited contributed significantly in the conduct of the present study. The aforementioned data are an invaluable help in seeing how the journey of nurse educators can be determined. Furthermore, it also aided the researcher in anchoring the present study on well-founded principles and studies where the influence of various nurse leaders being great and successful was used.

The studies on the journey of becoming a professional nurse: They are all in agreement that nurses should possess specific traits, attributes and personalities in order to successfully develop themselves. However, the researcher found that there is a dearth of studies related to specific characteristics that describe a great nurse educator or great Filipino nurse educator in particular [1] [15].

This study aimed to serve as a framework which will be beneficial in providing inspiration to both the students and nurse educators to continue practicing and demonstrating behaviors that are acceptable and motivating to others. It will strengthen their appreciation, love and commitment to the nursing profession, consequently, the results will provide more insights into the roles of the faculty members in the training and development of the students in becoming effective and efficient nurses in the future. Furthermore, this study will provide appropriate awareness of the contribution of nursing education to the over-all growth and development of the health needs of the people. Moreover, this will awaken the hearts and minds of the nursing practitioners the desire to examine their own attributes, traits and characteristics vis-a-vis the model of a great Filipino nurse educator, thus, enabling them to respond holistically to the demands of their profession. Since this study is aimed at developing a theoretical model of a great Filipino nurse educator, the results of the study shall serve as a basis for 
evaluating existing practices and activities designed to develop acceptable behaviors among students and practitioners. It will further justify changes or modifications in existing programs and training as well as in performance evaluation tools. Furthermore, the results will provide the administrators a framework that would enhance development of a great Filipino nurse educator or practitioner. Lastly, the results of this study will provide baseline data for future researches on nursing education, nursing practice and nursing research. The research methodology may be considered in other researches of similar nature. The collection of related literature and studies may also be of use as future references.

\subsection{Aim of the Study}

The aim of the study was to determine the characteristics and attributes of a great Filipino nurse educator.

\section{Methodology}

\subsection{Research Method}

\section{Grounded Theory}

This research is a qualitative study that employed a grounded theory methodology. Grounded theory (GT) refers to a set of systematic inductive methods of conducting qualitative research aimed toward theory development [16] [17]. The methodological strategies of grounded theory are aimed to construct middle-level theories directly from data analysis. The inductive theoretical thrust of these methods is central to their logic. The resulting analyses build their power on strong empirical foundations. These analyses provide focused, abstract, conceptual theories that explain the studied empirical phenomena. This particular study utilized the grounded theory which focused on the characteristics perspectives of different Filipino stakeholders from different parts of the world on what makes a Filipino nurse educator great [18]. In grounded theory, it starts from conceptualizing to constant comparative coding [19]. After the core category is arrived at and/or discovered, systematic coding starts, and is followed by theoretical sampling and deeper data analysis to discover more data and to see if the core categories discovered truly work, hence, making it grounded from writing of memos coming from the write-ups.

\subsection{Participants}

The researcher used purposive non-probability sampling where only those who are qualified, or those who possess the inclusion criteria were included. The inclusion criteria include that for nursing students, he is a bona fide Filipino student of any college or university in the Philippines, a second, third or fourth year Filipino BSN student and has consented to participate in the study; and for Nursing Professionals, he is a Filipino graduate of Bachelor of Science in Nursing, a licensed/registered Filipino nurse and a working in any field of nursing (e.g. community, institutional, academe, skills training institution). Exclusion 
criteria include those who are not nursing students and not nursing professionals. The participants were clustered according to their professional groupings. Undergraduate nursing students were coded as SN (SN1 - SN9), Post-Graduate nursing students were coded as PGSN (PGSN1 and PGSN2), professionals, educators or Clinical Instructors, nurse managers and leaders, professional nurses were coded as PN (PN1 - PN25), nurse managers were coded as NM (NM1 NM8) while nurse educators were coded as NE (NE1 - N9). Table 1 summarizes the 53 total number of participants according to their geographical locations and profession.

There were nine student nurses who participated in the study and their demographic data include: SN1 is a Filipino, a Bachelor of Science in nursing student and she consented to be part of the study. She took up nursing because it is in line with their family background. She has come to find out Nursing as a challenging yet very fulfilling profession. SN2 - SN9 are all Filipino, 4th year BSN student from the Philippines and have consented to be a participant of the study.

Forty-four professional nurses participated with the following demographic profile. PN1 is a Filipino, A BSN graduate and a licensed nurse in 2009. Currently, she is working as a dental staff nurse. She was only 21 when she came in KSA where she has stayed for six years already. PN2 is a Filipino, A BSN graduate and a licensed nurse in 2007. She works as a staff nurse in one of the general hospitals in Region 3; then he became an ER nurse in Yanbu, KSA and a supervisor in Mrafik from 2009 to present. PN3 is a Filipino, A BSN graduate and a licensed nurse in 2007. She is working as a staff nurse for 8 years, two years in the Philippines as ER NURSE and 6 years in the Kingdom of Saudi Arabia. PN4 is a Filipino, A BSN graduate and a licensed nurse. She has worked for 3 years in the Philippines and 4 years in the Kingdom of Saudi Arabia. In the Philippines, as a Staff Nurse (OB-Gynecology/NICU Department) then 1st 2 years in KSA as a Staff Nurse (OB-Gynecology OPD and ER OPD). At present, I am a Staff Nurse 2 in the University Medical Center/Family Medicine Department. PN5 is a Filipino, A BSN graduate and a licensed nurse. She started working in 1998 in the Philippines and at present, is a staff nurse in a military medical center at the renal transplant unit. PN6 is a Filipino, A BSN graduate and a licensed nurse in 2007 and has worked as a staff nurse for more than a decade, and has been an Associate Professor. Currently, she is working at Abu Dhabi, UAE. She is also a graduate of Master of Arts in Nursing from a Philippine University. PN7 is a Filipino, A BSN graduate and a licensed nurse from the Philippines. She has worked as a collector/teller/encoder in a company for 3 years and is presently working as a caregiver in Israel. PN8 is a Filipino, A BSN graduate and a licensed nurse and she is currently a registered transplant staff nurse in New Zealand. PN9 is a Filipino, A BSN graduate and a licensed nurse and has worked as a Clinical Instructor for 9 years and 2 years as Emergency Room nurse in the USA. PN10 is a Filipino, A BSN graduate and a licensed nurse Batch 2013 and right after graduation, she went to USA and is now working as a Medical/Relation 
Table 1. Participants' geographical location \& profession.

\begin{tabular}{|c|c|c|c|c|c|c|}
\hline \multirow{2}{*}{$\begin{array}{l}\text { Geographical } \\
\text { Location }\end{array}$} & \multicolumn{5}{|c|}{ Code of Participants } & \multirow[t]{2}{*}{ Total } \\
\hline & $\underline{\mathrm{SN}}$ & PGSN & PN & $\underline{\mathrm{NM}}$ & $\underline{\mathrm{NE}}$ & \\
\hline Australia & & & 1 & & & 1 \\
\hline Abu Dhabi & & & 1 & & & 1 \\
\hline Dubai & & & 1 & & & 1 \\
\hline Guam & & & & & 1 & 1 \\
\hline Israel & & & 1 & & & 1 \\
\hline KSA Tabuk & & 2 & 2 & 1 & 1 & 6 \\
\hline KSA Riyadh & & & 2 & & & 2 \\
\hline KSA Yanbu & & & 1 & & & 1 \\
\hline New Zealand & & & 1 & & & 1 \\
\hline Oman & & & 1 & & 2 & 3 \\
\hline Philippines & 9 & & 11 & 6 & 5 & 31 \\
\hline United Kingdom & & & 1 & 1 & & 2 \\
\hline USA & & & 2 & & & 2 \\
\hline Total & 9 & 2 & 25 & 8 & 9 & 53 \\
\hline
\end{tabular}

Assistant. PN11, is a Filipino, A BSN graduate and a licensed nurse in April 2012. From 2012 to present she has worked as Project Assistant II to Science Research Specialist. At present, she works as a staff nurse in ENT Hospital. PN12 is a Filipino, A BSN graduate and a licensed nurse, working as a staff nurse in Australia. Previously, he worked as clinical instructor and research employee in $\mathrm{Ma}$ lolos, Bulacan. PN13 is a Filipino, A BSN graduate and a licensed nurse and has started as a volunteer nurse in OPD then worked as a staff nurse in a General Hospital in the Philippines. He also became part of the RN Heals program of $\mathrm{DOH}$ in 2013, and worked as a private duty nurse in 2014. At present, he is an Operating Room nurse in the Philippines. PN14 is a Filipino, A BSN graduate and a licensed nurse from the Philippines and at present is a certified International Trauma Life Support Advanced provider in an orthopedic hospital in Dubai. PN15 is a Filipino, A BSN graduate and a licensed nurse in 2009 and a Master of Arts in nursing degree holder. He works as a staff nurse in Abu Dhabi, United Arab Emirates. PN16 is a Filipino, A BSN graduate and a licensed nurse. $\mathrm{He}$ is very active in his business ventures. PN17 is a Filipino, A BSN graduate and a licensed nurse and formerly a party-list representative. PN18 is a Filipino, A BSN graduate and a licensed nurse and a staff nurse in the Philippines for more than 25 years where he is assigned in different wards in the hospital. PN19 is a Filipino, A BSN graduate and a licensed nurse. For 27 years, he worked as a staff nurse in one hospital in the Philippines and worked for five years at the 
Operating Room in Saudi Arabia. PN20 is a Filipino, A BSN graduate, a licensed nurse and a staff nurse in Abu Dhabi assigned in the intensive care unit. PN21 is a Filipino, A BSN graduate, licensed nurse and works as a legislator. Previously, she was a clinical instructor for 20 years in a local college. She worked for more than ten years as a staff nurse in Saudi Arabia. PN22 is a Filipino, A BSN graduate, licensed nurse and works as a military nurse in the Philippines. PN23 is a Filipino, A BSN graduate, licensed nurse and works from the Philippines. He is also a medical doctor by profession, where nursing is her pre-med. He is a fellow of the Philippine College of Surgeons. He is connected to three hospitals in the Philippines. PN24 is a Filipino, A BSN graduate, licensed nurse and works as a staff nurse specializing in Intensive Care Unit in one hospital in the Philippines. PN25 is a Filipino, A BSN graduate, licensed nurse and works as a staff nurse in the Philippines.

There were eight nurse managers who participated: NM1 is a Filipino, A BSN graduate, licensed nurse and has worked for 2 years in a general hospital in the Philippines right after graduation and is now the head nurse in the Surgical Department in a tertiary government hospital in the Kingdom of Saudi Arabia. NM2 is a Filipino, A BSN graduate, licensed nurse and works as a head sister nurse with post graduate certification in different specializations in the United Kingdom. NM3 is a Filipino, A BSN graduate, licensed nurse and works as a Dean in the Philippines. She holds a Master's Degree in Nursing. She has been in nursing education for the past 25 years. NM4 is a Filipino, A BSN graduate, licensed nurse and an MA in nursing degree holder. She is an expert in Trauma Nursing and Emergency Nursing. She manages a 100-bed capacity hospital in the Philippines. She has extensive experiences in Nursing Administration. NM5 is a Filipino, A BSN graduate, and licensed nurse. She works as the Dean of the College of Nursing in the Philippines. She has been in Nursing Education for more than 30 years. NM6 is a Filipino, A BSN graduate, and licensed nurse. She is a Dean of the College of Nursing in the Philippines. She holds a Doctor of Philosophy in Nursing Education. She has been in nursing education for more than 25 years. NM7 is a Filipino, A BSN graduate, and licensed nurse. She is a holder of Doctor of Philosophy major in Educational Management and has been a Dean for more than a decade. NM8 is a Filipino, A BSN graduate, and licensed nurse. She is a Chief Nurse from the Philippines. She has been in nursing practice for 17 years.

Eleven Nurse Educators participated in the study: NE1 is a Filipino, A BSN graduate, and licensed nurse. She worked as a school nurse for 7 months, then a staff nurse for one and a half years. She also taught for 9 years in the same region until then she went to Dubai to work in a company. At present, she is a lecturer in nursing in the Kingdom of Saudi Arabia. NE2 is a Filipino, A BSN graduate, licensed nurse and has taught nursing for almost 12 years and is now working as a lecturer and assigned in Research Ethics in Oman. NE3 is a Filipino, A BSN graduate, licensed nurse and holds a degree in Doctor of Philosophy major in 
Educational Management from a university in Philippines. She has been a lecturer/reviewer of Maternity Nursing/OB Nursing in more than 100 Colleges of Nursing in the Philippines. She moved to Guam to accept a professorial job at the University of Guam. NE4, is a Filipino, A BSN graduate, licensed nurse and he has been teaching Perioperative Nursing for more than ten years. He is a lecturer and reviewer in Medical Surgical Nursing. NE5 is a Filipino, A BSN graduate, licensed nurse and has been a clinical instructor for six years. She is a lecturer of Medical Surgical Nursing. NE6 is a Filipino, A BSN graduate, licensed nurse and a clinical instructor in one of the universities in the Philippines. NE7 is a Filipino, A BSN graduate, licensed nurse and is a clinical instructor in Oman. Previously, he is a clinical instructor in Philippines. NE8 is a Filipino, A BSN graduate, licensed nurse and a lecturer/clinical instructor in one of the colleges of nursing in the Philippines. NE9 is a Filipino, A BSN graduate, licensed nurse and she is currently working as a lecturer in Oman. She has been a Staff Nurse, Asst. Chief Nurse, Head Nurse, Level III Academic and Clinical Coordinator, Faculty Coach Nurse Licensure Examination "Coach Program", Clinical Instructor/Nurse Educator/Lecturer in one of the colleges of nursing in region 3. NE10 is a Filipino, A BSN graduate, and licensed nurse. He started his career as a staff nurse to reinforce his knowledge and skills in the nursing profession. His MSN is major in Adult Health Nursing from 2008-2010. And then he focused in the teaching profession. NE11 is a Filipino, A BSN graduate, and licensed nurse and is currently working as a clinical instructor in the Kingdom of Saudi Arabia.

\subsection{Setting}

The study was conducted in the following countries: Australia, Abu Dhabi, Dubai, Guam, Israel, Kingdom of Saudi Arabia, New Zealand, Oman, Guam, United States of America, and Philippines from April, 2017-January, 2018.

\subsection{Procedure}

The study was approved by the St. Paul University Manila Ethics Review Board. The researcher started distribution of letters requesting participation to intended participants in this study. Upon consent to participate, the researcher gathered information using the open-ended interview guide. Follow up questions were inquired by the researcher during the interview once the need to probe arises during the interview periods. It was explained and emphasized to the participants their right to decline participation or later withdraw from the study. In consultation with the participants, a date was set for an interview within 1 week.

\subsection{Data Collection}

Qualitative data of the characteristics of a nurse educator were collected through semi-structured interviews via conducting face to face interview, interview via social media platforms like Facebook, Messenger, IMO, LINE and SKYPE. All 
interviews were tape-recorded and were transcribed verbatim. Each interview was covered with the following guide questions: "What are the characteristics and attributes of a great Filipino nurse educator?", "What are the requirements of a great Filipino nurse educator?", and "What are the achievements of a great Filipino nurse educator?", "What are the contributions of a great Filipino nurse educator?" and "How would you define a great Filipino nurse educator?" These questions allow the participants to share their experiences in their own words. The transcribed data were given back to participants to confirm and/or to modify findings. Data collection was stopped when saturation was reached.

\subsection{Data Analysis}

Data from interviews were analyzed and categorized using qualitative method of constant comparison towards a theory-generating process [17]. It first started with constant comparison methods on responses by using line by line and word by word analysis, separating items and ideas that are not similar and clustering those with same items and ideas. Through constant coding and analysis, concepts are formed and are categorized through establishing salient groupings among the gathered information until the point of saturation is reached. Concepts are then identified through reoccurrence and development of importance in deductive processing. The core variable then emerges through selective coding among the identified concepts where the categories are examined to ensure which categories have a relationship to the theory being developed. Categories are properly identified and consolidated through identifying inter-relationships among them. Concepts are weeded out through selective reduction in order to arrive at core categories, core variables, and eventually developing the theory grounded from the data gathered from participants.

In order to establish Rigor, four criteria were met based on the stipulations of Glaser: fit, workability, relevance, and modifiability [20].

\section{Results}

The data analyses led to identification of 26 core categories and subsequently 9 themes. Table 2 summarizes the categories and themes that define the characteristics of a great Filipino Nurse educator.

Theme 1-Highly Qualified

The Philippine law outlines a list of minimum requirements related to content knowledge and teaching skills that a highly qualified nurse educator would meet. In this study highly qualified means having education and certification, experience both in teaching and clinical, physical fitness and lifelong learning. He must be equipped by with the relevant educational requirements that are necessary to ensure appropriate knowledge, skills, attitudes to effectively if not greatly perform their purposes. This knowledge was gained through formal education, continuing education and experiential knowledge gathered through the years of working as a nurse and educator. 
"She is well-experienced, she can share a lot of things. She inspires based from her experience at the same time not only teach but also demonstrates and put it into practice".

“BSN graduate, registered nurse and with master's degree or MAN. Physically fit and of sound mind".

"Someone who has substantial bedside nursing experience and academic qualification".

Solid clinical experience is brought about by the nurse educator's exposure to the hospital, community and other clinical areas. As the saying goes, "One cannot teach, what you do not have". Truly, when a nurse educator possesses extensive hospital experience, she will be able to teach her nursing students the actual nursing practice.

Table 2. Categories and themes lifted from the responses.

\begin{tabular}{|c|c|}
\hline Emergent Themes & Comprising Categories \\
\hline $\begin{array}{l}\text { Highly Qualified } \\
\text { (Kwalipikado) }\end{array}$ & $\begin{array}{l}\text { Experience, Formal Education, Lifelong Learning } \\
\text { and Physically Fit }\end{array}$ \\
\hline Competent & Teaching Abilities \\
\hline (Natatanging & Leadership and Managerial skills \\
\hline Kakayahan) & Engages in Research and Accreditation \\
\hline \multirow{4}{*}{$\begin{array}{l}\text { Well-Rounded Personality } \\
\text { (Mabuting Pagkatao) }\end{array}$} & Positive Traits \\
\hline & Well-Rounded Personality \\
\hline & Versatile/Resilient \\
\hline & Sense of Humor \\
\hline \multirow{7}{*}{$\begin{array}{l}\text { Caring } \\
\text { (Mapagmahal) }\end{array}$} & Communicator of Care \\
\hline & Passionate/Compassionate \\
\hline & Inspires and Empowers \\
\hline & Committed/Goes Extra Mile \\
\hline & Transcends \\
\hline & Nurtures \\
\hline & Believes in Students Capability \\
\hline \multirow{4}{*}{$\begin{array}{c}\text { Spiritual } \\
\text { (Maka-Diyos) }\end{array}$} & Positive Relationship with Students, Parents, Colleagues and \\
\hline & Stakeholders \\
\hline & Fear of the Lord \\
\hline & Nursing Is Calling \\
\hline Role Model (Idolo) & Serves as Role Model \\
\hline Catalyst Agent & Innovative \\
\hline (Tagasulong ng Pagbabago) & Catalyst Agent \\
\hline Patriotic & Patriotic \\
\hline (Makabayan) & Rooted in the Family \\
\hline World-Class & Prepares the Next Generation \\
\hline (World-Klas) & Serving People in the World \\
\hline
\end{tabular}


Nurse educators teach students both in classroom and in clinical setting. In order for her to carry out the teaching role satisfactorily, he must be mentally and physically fit. This involves the educational qualifications of the great Filipino nurse educator that prepares him to assume his role as a nurse educator. The concepts and theories he learned through formal education enrich her with the needed knowledge a nurse educator must possess in order to convey and teach content to students, as well as deep understanding of the concepts and ideas being taught. He has sufficient knowledge on the content, context, pedagogy and students who will appreciate the intricacies that are bound up in the teaching and learning process.

The clinical experience he gained provided important and valuable experiential knowledge which equipped her ability to transfer knowledge so that the learners aspire and even own the knowledge and skills for themselves. The clinical experience in the hospital represents the most stressful part for the student due to lack of competence and knowledge. An organized, decisive and carefully planned clinical experience by the expert nurse educator results to an improved student's practical competence, elevates confidence, and increases motivation and self-esteem. Therefore a solid clinical experience of the nurse educator allows better teaching and learning among nursing students [21].

According to the Philippine Nurses Act, the faculty in a college of nursing teaching professional courses must 1 ) be a registered nurse; 2 ) have at least one year of clinical practice in a field of specialization; 3) be a member of good standing in the accredited professional organization for nurses; and 4) be a holder of a master's degree in nursing, education, or other allied medical and health sciences conferred by a college or university duly recognized by the Government of the Republic of the Philippines [22].

This theme also includes the characteristic of a nurse educator who loves learning and never allows stagnation to run into her system. They invest on their own education and models to their students the value for lifelong learning, from which both of them learn and grow together. A reflection on their part is happening in an effort to continuously improve. A great Filipino nurse educator continues to learn. She is not contented with her craft. This facilitates improvement of her skills, knowledge and competencies. According to the Scotland Teacher Education Review, continuing professional development assures a high level of expertise and enables the teacher to keep their professional skills and knowledge up-to-date. Remaining up-to-date with current issues and trends enables a professional to remain competitive with his peers [23]. Likewise, engaging in professional advancement activities brings in an increased level of confidence all of which will correlate to an improvement of the capability. They are highly skilled, motivated and committed workforce. It helps to ensure that further learning is progressed in a structured, practical and relevant way to guarantee efficiency in ones work setting. Moreover, being involved with these endeavors will improve nursing care and nursing practice that will benefit the patients 
and the society as a whole.

Theme 2-Competencies of Nurse Educator

A great nurse educator requires several competencies to effectively contribute to the attainment of high quality education and the production of effective, efficient, caring and skilled nurses who will be able to respond the health needs of the population they serve. The nurse educators in order to be great need to increase their proficiency in assisting student nurses to acquire all the knowledge, skills and attitude necessary to practice nursing. The identified competencies that underscore this theme include three categories namely: 1) teaching and clinical skills, 2) leadership and managerial skills and 3) engagement in research and accreditation.

"Focusing on important stuff, get the attention of the students".

"Prepared before going to class, direct to the point".

"Competent, with mastery; well-seasoned".

"Nursing expertise; indispensable experience and critical thinking".

"Furthermore, great nurse educator has been invited to more than one hundred nursing schools all over the Philippines to be their guest speaker, reviewer, lecturer, research panelists. That is from Luzon, Visayas and Mindanao".

"Should contribute immensely to the development of a superior nursing curriculum and effective Related Learning".

"Have presented his/ her research in an international audience."

"Contribute to the improvement of the curriculum by injecting innovative strategies that are step ahead of the standards".

"Research-oriented, doing research, instruction and extension, good in research".

Clinical skills of the nurse educator are crucial for the students in order for them to provide safe, competent and effective nursing care to patients in different settings. Instructional skills of the nurse educator involve experiential strategies that develop context-based nursing knowledge, skills and professional behaviors as well as formulate evaluation tools for teaching and learning experiences, and use results to monitor learners' performance and desired outcomes of courses

Leadership skills assume leadership roles at various levels for institutional governance, education development and enhancing nursing practice. Nurse educators demonstrate the skills of system management and leadership to create, maintain and develop desired nursing programs and shape the future of education institutions [24].

Every day, he faces different problems and should discover and produce new knowledge through research. A great nurse educator is also abreast in the promotion of excellence and maintaining the integrity in the nursing education through accreditation process that will assure the quality of education and the 
production of globally caring competent nurses.

Nurse educator possess a sound understanding of contemporary educational theories, principles and models underlying the design of curricula and the value of adult learning. Nurse educators demonstrate the skills and abilities to design, implement, monitor and manage curricula based on sound, contemporary educational models, principles, and best evidence.

The competencies revealed in this study are congruent with the powerful grounded theory research conducted by Reyes where the effective teacher is expert in all four areas of teaching namely subject matter, classroom management, instruction and diagnostic in teaching [1].

Theme 3-Well-Rounded Personality

Good personality always attracts people. Students love a nurse educator who possess well-rounded personality which leads to better communication, understanding and ultimately good result. Her qualities are so likeable as well as with her presentable personality. To the participants of the study, a great Filipino nurse educator is someone who possess A-Z positive traits of being Approachable, Brainy (Intelligent), Caring, Dedicated, Disciplined, Enthusiastic, Fulfilled individual, Godly person, Helpful, Innovative, Joyous person, Kind-hearted, Leader, Lovable, Motivator, Mother to students, Nurse, Optimistic in life, Passionate in teaching, Proactive, Passionate in teaching, Qualified in her profession, Respectful, Responsible, Skillful in her craft, Sense of Humor, Transformed individual, Understanding, Versatile, Wise (biblical meaning), X-factor, Yes attitude (open to change), Zealous educator.

“Kind, generous, patient, confident, strict but not lenient".

"Dedicated, Optimistic, have a positive outlook in life; patience; with lots of patience".

"Full of enthusiasm and with attitudes and qualities like caring, humble, and perseverant. Cohesive".

Having positive traits is a plus factor. It is needed in order to embrace a culture that accepts good behavior and shuns away bad attitude or trait. Positive traits such as integrity and honesty cultivate personality and influence the outer perceptions in order to develop nobility of the heart, mind and deed [25]. This is same with what Jones said that Nurse Education requires a teacher to be dynamic, supportive, caring, empathetic, challenging and knowledgeable [8]. Also, Raintree identified the top 5 qualities that make educators successful in nursing classes include the following: passion, patience, socially approachable, reflection and dedication [9]. And in the powerful study of Reyes, an effective teacher possesses the personal attributes, is cheerful, and is willing and motivated person always in the pursuit of continued professional growth [1].

Theme 4-Caring

The participants of this study have remembered their nurse educator about their experiences with him on how they feel in their presence. Students have 
identified and defined a great Filipino nurse educator who builds caring relationship with his students. Communication of love and care is shown by his teacher when she communicates with care through active listening finding meaning behind what a student says and checks with them if they have understood properly, in this way the dignity of the student is affirmed and helps in building a trusting relationship between the teacher and the student. Being a good communicator is not limited to being good or proficient in English communication but most on communicating care and listening heart. He nurtures. He believes in the capability of his/her students.

"Unselfishly shares his nursing knowledge; excellent communicator".

"Very understanding of her students, recognize and distinguish students who need help".

"Compassionate and knowledgeable in what they are saying, knows how to listen to the ideas of others".

"I conceived them in my hearth and truly love and care them so deeply".

On being Passionate/Compassionate, they have this inner satisfaction they enjoy and love what they do that makes a lasting impression in the lives of their student's minds. He cannot imagine himself doing something else than teaching, and that is clear in her mind and his heart beats that he loves his role of being one teacher.

A Great Filipino Nurse educator (GFNE) Inspires: There is enjoyment to encourage their students to reach beyond expectations and teach to be an example. The influence marks an impact in the lives of their students and here lies the essence of a great nurse educator, that is, when she able to produce new nurse sent to work in the vineyard of nursing, of touching lives and being touched.

On commitment, a great teacher spent more hours serving the students and his work. He shares her life and there is burning eagerness to educate students.

The intensity of power of the nurse educator exudes inspiration to his students-it transcends.

Caring as one of the defining characteristics of a great Filipino nurse educator: Students who have caring relationships with teachers are academically more successful and show greater pro-social or kind, helpful behavior. Great teachers according to participants tirelessly work in creating a caring, nurturing environment [26]. The identified nine characteristics of great teacher which focuses on caring that involves ability of the nurse educator to respect student, creating a sense of belongingness, being enthusiastic, caring and sets high expectations for all students [27].

Committed teachers view themselves as responsible for the success of their students, believes that all students can learn, know their students, subject, and themselves while continuing to account for the fact that students learn differently, they reach students and together, they enjoy their successes. Effective teachers believe that extra hours spent preparing and reflecting upon instruction are well 
worth the student outcomes-specifically with regard to student achievement [28].

Compassion is one attribute that is expected of a teacher. An effective nurse leader must be able to emanate compassion because of many reasons: role modeling among junior nurses, organizational profiling through representation and observing basic nursing context expectation [29] [30]. A compassionate teacher is excited about influencing student's lives and understands the impact they have.

\section{Theme 5-Spiritual}

A great Filipino nurse educator is looked up to by her students for possessing this sense of spirituality. Spirituality as revealed in this study covers fear of the Lord, looks at nursing as a calling, and having positive relationship with students, parents and stakeholders.

"God-fearing, have spiritual belief like Jesus and you do everything".

"Do unto others what you want others do unto you".

"Does not leave the MINDS, HEART and SPIRIT empty, Saintly patience".

"Give unlimited patience and dedication, charismatic".

"She taught me to start the day by reading the Gospel and reflect on it".

A great Filipino nurse educator embraces a connection to something bigger than herself. The connectedness he found to a bigger force allows her to align her thoughts, aspirations and works to serving him and that is through responding to the call of touching lives by teaching and by nursing. He fears the Lord, he considers Nursing as a Calling and not just a mere profession. Her work was the beat of her heart and her personal, mystical experience with her God rather than the work of a systematic academician. She illustrates humility of the hearts is essential. He used the inner voice of spiritual encouragement he heard from God to use it for God's kingdom purpose.

He always acts upon the bible principles, that everything he does glorifies God. For God is love so does he shows and communicates love and care to his students. He throws judgment away, accepts self and mistakes and learns from students. He leads her student to discover their purpose in life, as well as their identity to seek a meaningful connection with something bigger than oneself, which can result in positive emotions such as peace, awe, contentment, gratitude and acceptance. He leads others to transformation, igniting their candles that will shed light to others. He assists the students to see deeply into and through the events of their lives in order to discern their meaning. He is not just an educator of the mind but an educator of the heart. He loves his students unconditionally.

Filipinos are known for their spirituality (Maka-Diyos) and belief in the Sovereign Power. Spirituality is about meaning making, about how we make meaning in our lives [31] [32] [33], particularly as related to our overall life purpose. It is the development of self-awareness, a sense of interconnectedness of all things 
and a relationship to a higher power or higher purpose. Individuals like nurses do what they feel called to do-what gives their lives meaning [34].

Spirituality is always present in the learning environment. Given that life force is everywhere and the process of meaning making is happening all the time, people's spirituality is always present in the learning environment. Metanoia, is a change of heart. Spirituality is moving toward sense of greater authenticity or more authentic identity which was strongly related to a sense of God within, a higher self, the force or spirit alive within [33]. This is in consonance with the claim of Miller that spirituality is nourished not through formal rituals that students practice in school, but by the quality of relationship that is developed between person and world. We can, and must cultivate an attitude of caring, respect and contemplation to replace the narrow modernist view that world is a resource to be exploited [35]. The mutual respect in this teacher's classroom provides a supportive, collaborative environment [27].

A teacher who invites heart and soul into the classroom also find it essential to nurture their own spiritual development. This may mean personal practices to cultivate awareness, serenity and compassion as well as collaborative efforts with other teachers to give and receive support on the challenges and joys of entering this terrain with their students [33]. The most important quality of being a good nurse is having compassion [4].

Throughout time and across culture, the heart has been a symbol of compassion, eros, ecstasy and spirit. It is the heart that soars, the heart that breaks. The heart is sacred, suffering and or triumphant. The concept of heart has been linked to notions of the soul, a sacred inner center [36]. Heart is the seat for the soul, a site of compassion, as an embodied awareness of the infinite, the very core of being [37]. They provide a multitude of tactics to reach students. Great teachers view themselves as responsible for the success of their students, and believe that all students can learn, know their students, subject, and themselves while continuing to account for the fact that students learn differently, they reach students and together they enjoy their successes. Effective teachers believe that extra hours spent preparing and reflecting upon instruction are well worth the student outcomes-specifically with regard to student achievement [28].

Theme 6-Role Model

A great Filipino nurse educator lives and led by example in order to be able to guide their students. They model behaviors they expect in their students. Consequently, when students practice these expected behaviors, effective teachers are able to coach students along the way. They do not just idolize them for the knowledge and skills they possess but with everything they live by example of what an epitome nurse should be.

"Epitome of being a successful Filipino nurse educator".

"I think I am what I because of my great teachers. I have adopted some of those".

"Role-Model while she is teaching us the basic". 
"Perfect example of a globally competitive nurse worth emulatin".
"Genuine role models of the youth and of the societ".
"Set the example of providing tender loving care with much gust".

Being great nurse educator is achieved through role modeling. Modeling and coaching are additional characteristics of an effective teacher's repertoire [38]. Nurse educators play a pivotal role in strengthening the workforce, serving as role models [3]. A role model is a person who inspires and encourages us to strive for greatness, live to our fullest potential and see the best in ourselves. A role model is someone we admire and someone we aspire to be like. We learn through them, through their commitment to excellence and through their ability to make us realize our own personal growth. We look to them for advice and guidance. A role model can be anybody: a parent, a sibling, a friend but some of our most influential and life-changing role models are teachers.

Theme 7-Catalyst Agent

A great Filipino nurse educator can shift gears and thinks outside the box, outside the classroom and outside the norm. He makes it a point to make learning experience exciting and memorable for students. He always seeks to bring his students to the next action packed level. He lives outside of his own needs and remains sensitive to the needs of others including students, parents, colleagues or community. He is never threatened to try new ways, to experiment. He keeps his core principles strong but keeps on evolving with the changing times. He embraces technologies and confidently moves forward into the future.

"They are the catalyst that will hold the future. And that change will be for the common good and welfare of all student of life, for life".

"Greatness only comes if there is a change in the profession, the nurses and students we serve". "Nurture, Assert, Reform and Serve. One who makes it herl his responsibility to improve our country, our people, the nursing profession and the nurses and the Filipino people".

Striving for excellence is an important part of professionalism in any occupation. Quality teaching in higher education matters for student learning outcomes [39]. They further added that teaching quality throughout the world is also influenced by contextual shifts within the higher education environment. Current factors influencing the quality of teaching include: the internationalization of higher education, the increasingly broadening scope of education and greater diversity of student profiles, the rapid changes in technology, which can quickly make program content and pedagogies obsolete, the demand for greater civic engagement of graduates and regional development of higher education, the increased pressures of global competition, economic efficiency, the need to produce a skilled workforce to meet the challenges of the 21st century.

An effective teacher is concerned with his own continuous learning process and reflects on all elements of performance in an effort to continuously improve. He continuously learns and grows as he expects his students to learn and grow. 
He serves as a powerful example of lifelong learning as they find ways to develop professionally. They exude positive attitude about life and teaching [40]. Teaching is a complex, multifaceted activity, often requiring us as instructors to juggle multiple tasks and goals simultaneously and flexibly. Effective teaching involves progressively refining our courses based on reflection and feedback. Teaching requires adapting. We need to continually reflect on our teaching and be ready to make changes when appropriate. Knowing what and how to change requires us to examine relevant information on our own teaching effectiveness [41].

Theme 8-Patriotic

One of the outstanding characteristics of a Filipino in general is to be patriotic. In this study, the participants have identified one great characteristic that defines a great Filipino nurse educator is to be loving to his country and its people, someone who chooses to serve the country and in the event that he chooses to work abroad, or stays for lifetime where he was born, he takes pride of his heritage and work. He personifies the beauty and uniqueness of the Filipino culture. She represents and shows the values of being Filipino and teaches his students to let these values linger long in their lives. Patriotism is one of the defining characteristics of a great Filipino nurse educator.

"Serve our countrymen even in their own little ways. It takes great courage and patience to be one-that's why I consider them great".

"Take proud of his/ her heritage and work. Helshe never forgets to look back to where hel she came from."

"Stay in the Philippines to really form nursing graduates, must teach first the youth in his country".

"Considers also what is of great value to the Filipino learners, loves God, her country and her people".

"If the Nurse Educator can transform the student to be proud as Filipino and embrace their beauty, the uniqueness, culture, values and faith, makes it her/ his responsibility to improve our country, our people, the nursing profession and the nurses and the Filipino people. Unconditional loyalty as a Filipino and understands and loves his/ her work".

"The need to hone learners to be good citizens, Filipino-known for having open arms to accept and care for her students whoever and whatever they are".

Nationalism is a banner of freedom proclaiming the national interest of the people, to be protected and safeguarded by themselves so that the fruits of their efforts and the wealth derived from their God-given resources shall accrue to them and then enable all of our people to rise above poverty and march on to prosperity, contentment and dignity (Recto, https://www.thefilipinomind.com/).

Filipino patriotism is expressed through the Panatang Makabayan (Patriotic oath), I love the Philippines-the land of my birth, Home of my race-who kept me and has been helping me... To become strong, industrious and honorable. I 
love the Philippines-and for this... I will heed the counsel of my parents, I will obey the rules of my school, I will perform the duties of a patriotic citizen, I shall Serve, study, and pray faithfully. I shall offer my life, my dreams and all my endeavors... To my country [42]. When each Filipino, loves his country and its people, serve it, obey his parents, observe the laws and perform duties of a Filipino citizen, he/she is considered to be patriotic. In the modern times, where most of the overseas Filipino workers are represented by the nurses among healthcare providers, they are called as Bagong Bayani (new heroes of the modern and present time).

\section{Theme 9-World Class}

A great Filipino nurse educator is a source of pride globally. He is a source of inspiration. Anywhere and everywhere, each nurse working is influenced by his great Filipino nurse educator. Every single way of a teacher's motivation to a student contributes to a student's evolving attitude toward a particular subject or activity. In other words, you never know when a teacher influence stops, until she brings out the best in that student.

"Their impact as globally we were able to produce excellent nurses working abroad".

"A great Filipino nurse educator did her job especially to their students who are working as OFW (overseas Filipino workers)".

"Someone who's molding the future nurses".

"Shel he has produced countless nursing graduates who are now working in many places around the world. You name it, USA, UK, Middle East, Europe, in Asia and of course in the Philippine".

"Shel he can prepare nurses for clinical (hospital) and academe (school) exposure not only for the Philippines but develop them to be world class nurses".

Nurse educators play a pivotal role in strengthening the workforce, serving as role models, and providing the leadership needed to implement evidence-based practice and improve patient outcomes [3]. Most nurse educators will also act as role models and advisers, helping students along their journeys toward becoming successful nurses [6]. This was supported by one study who discussed the important role of a nurse educator in the School of Nursing. She said that a mediocre teacher tells. The good teacher explains. The superior teacher demonstrates, but the great teacher inspires [7]. A nurse educator is a trained nurse that educates and trains future nurses. This is a lasting legacy that is engraved in the heart of a great Filipino nurse educator as according to the participants [6].

\section{Discussion}

The study presents the theory that emerged from the data and insights taken from the participants. Every concept that contributes in the development of the theory with indispensable explanation on how it applies in the development of 
the defining characteristics of what makes a great Filipino nurse educator was explained. This study stipulated that Spirituality is central and essential in achieving the greatness of a Filipino nurse educator. Based on the information collected in this study, the following defining characteristics were identified:

Highly Qualified (Kwalipikado) which refers to the set of qualifications of a Filipino nurse educator. These qualifications include: having theoretical, practical and conceptual knowledge and skills gained through formal education; the years of experience in teaching; the fitness of the nurse educator physically and mentally and the continuous pursuit for learning through trainings, seminars and formal education such as master's and doctor's degrees.

Competencies (Natatanging Kakayahan) refer to the skills involve teaching skills and clinical skills, leadership and managerial skills and engagement with research and accreditation. Teaching skills refer to the ability of the teacher to use repertoire of instructional strategies that lead students to be involved in the learning process. This involves engaging student's engagement in class, use of simple terms, selecting appropriate instructional materials, monitoring student's performance and providing useful feedback. The clinical skills refer to the nurse educator's proficiency in teaching students practical or laboratory that focuses on the utilization of nursing process in the nursing care management. The level of proficiency developed over years of experience during prolonged exposure while teaching in different clinical, hospital or laboratory settings. Leadership and managerial skills refer to the administrative roles, organizational skills, shared decision making and teamwork as well as community building roles of a nurse educator. Engagement in research and accreditation are two important skills of a nurse educator that sees to it that quality of education is achieved.

Well-rounded Personality (Mabuting Pagkatao) pertains to the well-loved positive attributes of a nurse educator. Caring-this refers to the caring behaviors of a nurse educator that is shown through her communication, of being passionate/compassionate, of inspiring and empowering, of being committed, of nurturing, and he/she transcends and believes in the capacity of his/her students.

Spiritual (Maka-Diyos) refers to the central core of the defining characteristics of a nurse educator who fears God, the God of Love, views nursing as a calling where he is made to serve for the glory of God and in service of people by maintaining a positive relationship with them (the students, parents and stakeholders).

Role Model (Idolo) pertains to the capability of the nurse educator to influence future nurses through his motivation, coaching, living and leading by example. Catalyst Agent (Tagasulong sa Pagbabago) pertains to the characteristic of a nurse educator who pursue transformations in teaching and learning matters towards effectiveness, improvement and development. The nurse educator innovates and abreast with the technological explosions and constant contextual shifts in the higher education. He keeps his core principles strong but keeps on evolving with the changing times.

Patriotic (Makabayan) refers to the unique characteristic of a Filipino who is grounded (rooted in the family), loves his country and its people by serving it 
and bringing the prestige of the Philippines anywhere in the world he maybe. World Class (World-Klas) is a source of pride globally. He prepares the next generation and his/her students are his/her legacy.

Each characteristic is significant because all are important in describing what a great Filipino nurse educator is. One characteristic cannot be absent nor removed for it will not decipher the puzzle of what completes the defining characteristics of a great Filipino nurse educator. Total greatness is not an end product, it is an ongoing, deliberative process. Teacher's greatness is a lifelong pursuit. Greatness is the result of many factors, including aspects of the Filipino nurse educator's educational background, clinical and teaching experience, personality, spirituality, her qualities that resonates with his students years after leaving the great teacher's classroom, his influence and role modeling, his being grounded and rooted to his country of origin and his continuous pursuit for excellence. The succeeding figure gives an elaboration on how such journey in the making of a great Filipino nurse educator is achieved, the Gutierrez's 8 sides Theory in the Making of a Great Filipino Nurse Educator.

\section{The Theory}

Figure 1-GUTIERREZ' 8 sides Theory for Great Filipino Nurse educators showed the process of achieving greatness of a Filipino nurse educator. The journey to achieve greatness as nurse educator is a lifelong process. What lies towards greatness of a Filipino Nurse educator all originates from spirituality as the central theme that was identified in this study. The religious faith, the spirituality (pagiging Maka-Diyos) of the Filipino nurse educator is connected to the Divine Power who called him in the profession and vocation of Nursing and Teaching. As St. Paul wrote, Christ is the center of his life; he/she follows and imitates Christ, doing everything in reference to him. His life as a nurse educator becomes meaningful when it is used for a purpose to glorify God and maintain a good relationship with people. He finds fulfillment in intelligent fellowship and responsible leadership in meeting their responsibilities to God, country, and fellowmen.

In the Philippines, Roman Catholicism is the dominant religion practiced by $85 \%$ of the population [43]. The Philippines is the only country with a predominantly catholic population. As a result of four centuries of Spanish Catholic colonial rule [44], the Catholic faith has become a part of the Filipino culture [45]. Many Filipinos dutifully attend mass and services so they can incorporate virtues into their daily live and these practices are intricately interwoven into cultural meanings of identity, family and community [46] [47]. Spirituality is defined as a felt connection with a non-metal, non-emotional and non-physical aspect of being. Spirituality can be seen as comprising elements of meaning, purpose and connection to Higher Power or something greater than the self [48]. The religious faith, Spirituality (pagiging Maka-Diyos), of the Filipino nurse educators is connected to the Divine Power. He/She is called by God in Nursing. 


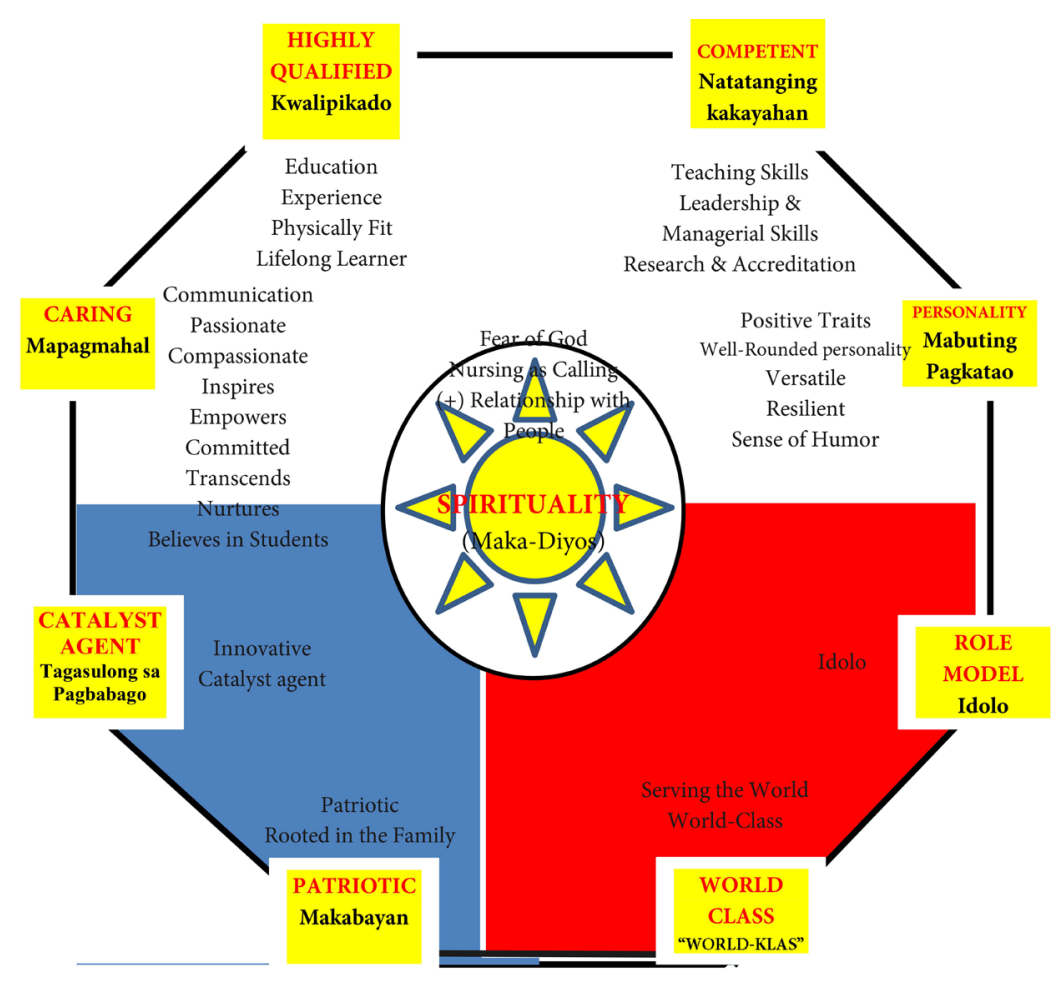

Figure 1. GUTIERREZ' 8 sides theory for great Filipino nurse educators (Ang Tanging Pilipinong Gurong Nars).

When the nurse educator acknowledges the Supreme Being who is greater than him and he fears Him and acknowledge that He is the God of love, he then based all her works from this Bible principle, "Go therefore and make disciples of all nations... teaching them everything that I have commanded you" [49]. $\mathrm{He}$ considers himself called to serve and give meaning and purpose to his life in building God's kingdom. He assists students to seek deeply into and through the events of their lives in order to discern meaning. He works as much from her heart and her personal, mystical experience with her God rather than the work of a serious or systematic academician. The students put their faith in the words of their teacher and when this happen, the teacher has great responsibility to the student-that is, to be of service to student, and that is to love people just the way they are, teaching by example and always wants what's best for the students, and therefore introduces the student to an unconditional love within. He follows God and His commandments to love God above all and love his neighbors as he loves himself... same as he loves his students, his colleagues, parents, patients and significant others.

The heart symbolizes spirit and soul, where he shows caring, with his attributes of being compassionate/passionate, committed, transcending, becoming source of inspiration and empowerment, nurturing and believing in his students capabilities. He views nursing as a calling, he is made to serve for the glory of God. The finding in the current study is similar with the claim of one author [4], that the most important quality of being a good nurse is having compassion. Like- 
wise, the current study claims on the personality traits of a nurse educator to be dynamic, supportive, caring, empathetic, challenging and knowledgeable [8]. Raintree further establish this claim when he said that the top 5 qualities that make educators successful in nursing classes include the following: passion, patience, socially approachable, reflection and dedication [9].

The completion of preparatory baccalaureate program in Nursing allowed her to gain valuable knowledge and skills in order to teach in the higher education. Education is the immovable tool that denotes a nurse educator as being great. The many years of formal education from undergraduate to graduate and post-graduate level is the first step towards being a great Filipino nurse educator. This is subsequently followed by accepting a role as a faculty in a college of nursing where the actual role of the teacher is practiced and from which all her actions and thoughts are connected with the Higher Power, spirituality (pagiging Maka-Diyos).

The great Filipino nurse educator excels in the tri-focal function in higher education which is research, instruction and community extension. Aside from formal education, the extensive clinical experience has equipped that individual with the knowledge and skills he ought to acquire in order to share to his nursing students. The clinical experience he gained has sharpened her clinical skills which serve as her tools and foundation in executing practical, clinical and laboratory teaching skills. As stipulated in R.A. 9173, that apart from the BSN degree that the additional requirement of clinical experience and units in master or doctor are pre-set requirements [22]. An effective teacher is someone with a post-graduate degree holder in a field of specialization [1]. When this educated, certified and experienced with clinical practice nurse decides to move from institutional nursing into the nursing academe on higher educational institution, he carries along with him these extensive clinical experience and theory. The experiential learning he achieved while teaching year by year increases his proficiency. Exposure in the clinical area as a staff nurse will benefit the nurse educator in ensuring that he will be able to teach his students and learners properly because the nurse educator is expert in actual clinical nursing practice. This is congruent with the study that said that teacher's effectiveness is associated with experience [50]. The experienced teacher supports greater student learning for their colleagues and the school as a whole as well as for their own students [51]. Furthermore, level of proficiency acquired by a nurse through years of experience that once a nurse becomes expert, she serves as a coach, mentor and role model [52]. Coupled with being physically and mentally fit and continuous and life longing for knowledge, the nurse educator becomes highly qualified in teaching.

As he assumes a role from clinician to nurse educator whether as a lecturer or clinical instructor, this individual starts to achieve competencies (Mga Natatanging Kakayahan) in instruction, communication, leadership and by being knowledgeable with the concepts and theories of what she taught in nursing 
education. She engages in research and accreditation to make sure that quality in education is achieved. As he develops these competencies, the central core of his spirituality and patriotism remain strong and intact in his system and that his personality exudes to influence and eventually serve as a role model (Idolo) for students in dreaming to become nurses and eventually will become productive and transformed global nurses.

The well-rounded personality (Mabuting Pagkatao) of a nurse educator composed of the attributes and characteristics that are inherent and unique within each individual which define his unique teaching styles based from his values, principles, perceptions, personality and experience of also being inspired by his former nurse educator/s. Reason to become a teacher in higher education is due to the passion and motivation she experienced from lecturers during her nurse education [8]. The personality traits define how this nurse educator handles a class both in and out of the classroom in order to provide quality education and eventually will inspire his student to become a transformed individual who saw his purpose and meaning of life through the teacher's influence and role modeling. Most nurse educators will also act as role models and advisers, helping students along their journeys toward becoming successful nurses [6]. Educators play a pivotal role in strengthening the workforce, serving as role models, and providing the leadership needed to implement evidence-based practice and improve patient outcomes [3]. Equally stated in the study of Reyes, an effective teacher possesses the personal attributes, virtues and teaching methods that nurture a favorable teacher-student relationship [1]. He symbolizes an effective teacher as someone who draws inspiration from both within and outside the school. A metaphor statement about great nurses is that if butterfly reproduce, nurses on the other hand, replicate [12]. An excellent nurse produces another great one and inspiring others to be a great nurse.

Fundamentally directed by his spirituality (Maka-Diyos), patriotism (Maka-Bayan) and his well-rounded personality (Mabuting Pagkatao), the nurse educator fully demonstrate the richness and complexity of the faculty role as he develops his competencies (Natatanging Kakayahan). He develops knowledge and instructional skills along with good communication skills and leadership skills. This finding is congruent with the study made Reyes that a teacher must have subject matter expertise [1], classroom management expertise, instructional expertise, and diagnostic expertise and that and in order to perform their jobs well, they must have excellent leadership skills and an in-depth knowledge of their fields [6]. The World Health Organization who identified core competencies of nurse educators confirms the findings in this study wherein a nurse educator is competent in nursing practice, educational theory and conceptual learning, teaching and learning in the clinical area, integration of theory and practice, assessment and evaluation of students and course/program outcomes, educational program development and evaluation, program management and administration, leadership and advocacy, effective communication, collaboration 
and inter-disciplinarily, research and professionalism [24].

Through the years of assuming the teaching role, and the development of competencies required of a nurse educator, and the ensuing influence, role-modeling and mentoring that lies within the journey of becoming great nurse educator, he remains a student forever and never settle for mediocrity. He moves forward and he innovates. A great Filipino nurse educator is personified by someone who always aim for continuous excellence in order to hone further her skills thus improving her craft in teaching and learning and it ensures that the knowledge of the nurse educator is relevant and up to date. Consequently, when a Filipino nurse educator meets international standards of quality and excellence, when he develop learners into a wholesome individual who will conquer the world, who are able to work in various parts of the world (world-class), that denotes what a great Filipino nurse educator is. For the students themselves, are the outcome of the life and work of the Filipino nurse educator. If the student becomes successful, then the nurse educator becomes great. Nurses should be prepared because technology is forever changing, people are getting sicker and evidence-based information is focusing on a broader array of practice issues, education and prevention and the findings of Reyes wherein the effective teacher is willing and motivated person always in the pursuit of continued professional growth [1] [10].

Finally, the researcher has discovered that the road to greatness of a Filipino nurse educator is all attuned with the strongest core of being spiritual and patriotic which makes it very Filipino. This demarcates what is great Filipino nurse educator and what is not. The findings of this study are contrary to what Jones (2012) said that to be a successful academic in nursing education, only two core ingredients are required: practice experience and teaching skills. Conversely, it is congruent with one study that explains that academic nurse educators must possess the required clinical and educational competencies and possess key attributes [7].

Hereafter, the final piece of the laborious work of the researcher in eliciting respondents' view of what is a great Filipino nurse educator was developed into a theory shown through the figure of 8 (eight) which reflects what a great Filipino nurse educator is. It encapsulates eight (8) defining characteristics that personifies a Filipino nurse educator as a great one. Eight symbolizes that which is beyond nature and its (inherently limited) perfection. Eight represent totality. It symbolizes harmony and balance, abundance and power. Eight signifies infinity, a symbol of new life. It is a symbol of love and friendship, the prudence and the thinking referred to as Tetrarchy's by the Pythagoreans and for the Japanese, eight means multiplicity [53].

The 8-side figure has equal bands of royal blue and scarlet red and white shade that is similar to the Philippine flag. Blue stands for the willingness to sacrifice oneself. Red symbolizes courage and patriotism. The eight-rayed golden sun on the Philippine flag symbolizes unity and sovereignty which represents the 
unity of the characteristics of a nurse educator that are encompassing to define what it takes to be a great one. The symbolism declares that the sun represents the gigantic steps made by the nurse educators as sons of the country along the path of progress and civilization. In consonance with the journey of being great Filipino nurse educator, he gives blue, red and white color that brings pride to the Philippines by being courageous, patriotic, of service and united with the goal of his country towards progress and civilization that is accomplished through the inspiration and role modeling he demonstrated to produce and strengthen the workforce of Filipino global nurses that makes her world-class (World-Klas).

What completes the definition of being great one harmonizes the presence of 8 characteristics: Highly qualified (education, experience, fitness and lifelong learning), competence in practice of teaching and nursing, well-rounded personality which is attuned with the strong core of spirituality and patriotism gushing through the blood of a Filipino anywhere and everywhere he goes making her world-class through her role modeling; her caring behavior and constant quest for changes as a catalyst agent. He multiplies compared to that of a butterfly who reproduce, he replicates another great one and inspiring others to be a great nurse. Her abundance of love is like an oxygen that gives life to the dream of his student to become transformed individual. Her influence is infinite. He is a total person, with total commitment for a total relationship with people-students, parents, patients, colleagues, administrators, people of the community and his family. His totality is dependent on the Highest Omnipotent power, the One who called her to serve, that governs his life giving meaning and purpose. This is the central or the core of the theory represented by the circle in the middle. Second most important to his connectedness to the Supreme Being, a nurse educator will not be great without family members, love ones, nursing students and colleagues and other stakeholders. These groups of people can make or unmake a nurse educator. Success in an organization, phenomenal growth in benefits and compensation, improvement of working conditions and growth of the industry can all be attained through the maintenance of harmonious relationship between and among all stakeholders. Fostering therapeutic relationship with all stakeholders, fosters mutual trust and respect that nurture faith and hope while being sensitive to others and assisting their gratification of their physical, emotional and spiritual needs through the knowledge and skills of the nurse educator [54]. As such, being pro-God, pro-people, pro-family and pro-environment signifies being a great nurse educator.

\section{Conclusion}

The researcher concludes that there are defining characteristics of a great Filipino nurse educator. To be a great Filipino nurse educator, one has to attain certain requirements or qualifications, made contributions and achievements and leaves behind a legacy that will be etched in the minds and heart of all stakeholders. The great Filipino nurse educator is defined by her characteristics. In 
this study, she is defined by her 8 attributes other than spirituality as the central core. The demarcation of being great from who is not is the central core of being a Filipino who is patriotic and spiritual. A great Filipino nurse leader contributes to the national and world by developing professional nurses who will serve their people through their skills, attitudes and competencies who were influenced by their former nurse educators. Spirituality encompasses being governed by the Supreme Omnipotent Being and that the nurse educator considers her profession as a calling as she personifies the attributes of being competent, caring and with well-rounded personality, role model, patriotic, catalyst agent in the whole world.

\section{Acknowledgements}

With unfathomable gratitude, this researcher acknowledges the following who have shared their generous and self-sacrificing assistance in the making of this paper. Administration of St Paul University Manila through its President, Sr. Ma. Evangeline Anastacio, SPC, Dr. Nieves Medina (+), former Dean of the Graduate School. Thanks to the College of Nursing and Allied Health Sciences (CNAHS): its Dean, Dr. Jennifer Joy Olivar, the college professors especially Dr. Wireen Leila Dator, Sr. Flordeliza Deza, Dr. Prince Germano, Dr. Lino Reynoso, Dr. Portia Vitug, Dr. Elizabeth Ramos, Dr. Malou Furio, Dr. Irma Bustamante, Dr. Fe Espinosa, Dr. Glenn Guira, Dr. Rhoda Reyes, for the warm support, and providing a model of what a leader and manager should be. Thanks to Dr. Lily Famadico, Dr. Ma. Encarnacion Dychangco, Dr. Portia Vitug, and Dr. Elizabeth Ramos for their intelligent and esteemed review and feedback on the paper. Special thanks to Dr. Rhoda Reyes, her dissertation adviser and Ms Fe Nadonga, CNAHS secretary.

To her family-Tatang Irineo Villanueva and Ima-Juanita Flores and her siblings, for the reinforcement and inspiration; for dreaming with her; for teaching her about God, love, and family. Robert, her husband for the support, her children, Louise Noreen and Johnroe.

Thank you to the 53 participants of this study from several countries, her colleagues from the Department of Nursing, University of Tabuk, Tabuk, Kingdom of Saudi Arabia, for their encouragement and support, to her students: past, present and future, for inspiring and motivating her to continue teaching in the Nursing profession. Finally, to the Almighty God, the Great Teacher, best role model of teaching, possessing the superlative adjectives of a great teacher from $A-Z$, an inspirer and motivator who shed light of understanding every details that happened in the researcher's life journey, anywhere and anytime.

\section{Conflicts of Interest}

The author declares no conflicts of interest regarding the publication of this paper.

\section{References}

[1] Reyes, F.C. (2015) Profile of an Effective Teacher. http://avrotor.blogspot.com/2015/10/part-1-profile-of-effective-teacher.html 
[2] Eta, V.E., Atanga, M.B., Atashili, J. and D’Cruz, G. (2011) Nurses and Challenges Faced as Clinical Educators: A Survey of a Group of Nurses in Cameroon. Pan African Medical Journal, 8, 28.

http://www.ncbi.nlm.nih.gov/pmc/articles/PMC3201592 https://doi.org/10.4314/pamj.v8i1.71085

[3] Bartels, J. (2015) Your Career as a Nurse Educator. http://www.nsna.org/Portals/0/Skins/NSNA/pdf/Imprint_Jan05_educator.pdf

[4] Koch, N. (2016) What Makes a Great Nurse? http://allnurses.com/nurses-rock/what-makes-a-797260.html

[5] Sherman, R.O., Bishop, M., Eggenberger, T. and Karden, R. (2007). Development of a Leadership Competency Model from Insights Shared by Nurse Managers. Journal of Nursing Administration, 37, 85-94. https://doi.org/10.1097/00005110-200702000-00011

[6] EveryNurse.org, 2016. https://everynurse.org/careers/registered-nurse

[7] Hunt, D. (2015) Transitioning from Clinical Nurse to Educator. Faculty Nurses Magazine.

[8] Jones, M. and Alony, I. (2011) Guiding the Use of Grounded Theory in Doctoral Studies-An Example from the Australian Film Industry. International Journal of Doctoral Studies, 6, 95-114. http://ijds.org/Volume6 https://doi.org/10.28945/1429

[9] Raintree, R. (2012) Top 5 Qualities That Make Educator Successful during Class. http://www.nursetogether.com

[10] Brown, V.M. (2012) My Journey on Becoming a Nurse. https://books.google.com.ph/books?id=de3TAQAAQBAJ\&pg

[11] Nkowane, A.M. and Ferguson, S.L. (2016) The World Health Organization Launches the 2016-2020 Global Strategic Directions for Strengthening Nursing and Midwifery. Nursing Economics, 34, 206.

[12] Florita, M. (2016) Nursing Metamorphosis: The Journey of a Registered Nurse. http://nurseslabs.com/nursing-metamorphosis-journey-registered-nurse

[13] Leslie, A. (2015) A Great Nurses' Journey. https://prezi.com

[14] Mc Hugh, M.D. and Lake, E.T. (2010) Understanding Clinical Expertise: Nurse Education, Experience, and the Hospital Context. Research in Nursing \& Health, 33, 276-287. https://doi.org/10.1002/nur.20388

[15] Sheer, B. (2007) Nurse Practitioners on the Move: The Journey to the United States. http://www.medscape.com/viewarticle/560673_4

[16] Charmaz, K. (2015) Qualitative Research: Grounded Theory: What Is It? http://guides.temple.edu/groundedtheory

[17] Strauss, A. (1987) Qualitative Analysis for Social Scientists. Cambridge University Press, Cambridge. https://doi.org/10.1017/CBO9780511557842

[18] Glaser, B. (1992) Basics of Grounded Theory Analysis: Emergence vs. Forcing. Sociology Press, Mill Valley.

[19] Glaser, B. (2012) Stop, Write: Writing Grounded Theory. Sociology Press, Mill Valley.

[20] Glaser, B. (1978) Theoretical Sensitivity: Advances in the Methodology of Grounded Theory. Sociology Press, Mill Valley.

[21] Dale, B., Leland, A. and Dale, J.G. (2013) What Factors Facilitate Good Learning Experiences in Clinical Studies in Nursing: Bachelor Students' Perceptions. Interna- 
tional Scholarly Research Notices, 2013, Article ID: 628679. https://www.hindawi.com/journals/isrn/2013/628679 https://doi.org/10.1155/2013/628679

[22] Republic Act No. 9173. Philippine Nursing Act of 2002. Article III, 5-6. https://www.officialgazette.gov.ph/2002/10/21/republic-act-no-9173/

[23] Scotland Teacher Education Review (2016) The Importance of Continuing Professional Development.

http://www.reviewofteachereducationinscotland.org.uk/the-importance-of-continui ng-professional-development.html

[24] World Health Organization (2016) Nurse Educator Core Competencies. WHO Press, World Health Organization, Geneva.

https://www.who.int/hrh/nursing_midwifery/nurse_educator050416.pdf

[25] Davenport, B. (2016) Character Traits Essential for Happiness. http://liveboldandbloom.com/10/relationships/good-character-traits

[26] Zakrzewski, V. (2012) 4 Ways Teachers Can Show They Care. Greater Good Magazine. greatergoodberkeley.edu.

[27] Orlando, M. (2013) Nine Characteristics of a Great Teacher. http://www.facultyfocus.com

[28] Bratton, S.E. (1998) How We're Using Value-Added Assessment. The School Administrator, 55, 30-32.

[29] Marquiz, B. and Huston, C. (2013) Leadership Roles \& Management Functions in Nursing. Lippincott Williams \& Wilkins, Philadelphia.

[30] Olivar, J.R. (2015) The Making of the Successful Filipino Nurse Leaders. A Doctoral Dissertation, University of St. Paul Manila, St. Paul.

[31] English, L. and Gillen, M. (2000) Addressing the Spiritual Dimensions of Adult Learning: What Educators Can Do. New Directions for Adult and Continuing Education, No. 85. Jossey-Bass, San Francisco. https://doi.org/10.1002/ace.8503

[32] Hunt, C. (2001) Turtleback Rider. Metaphor as a Vehicle for Reflective Practice. In: Proceedings of the 31 st Annual Conference of SCUTREA (Standing Conference on University Teaching and Research in the Education of Adults), University of East London, London, 202-206.

[33] Vella, J. (2000) A Spirited Epistemology: Honoring the Adult Learner as Subject. New Directions for Adult and Continuing Education, 2000, 7-16. https://doi.org/10.1002/ace.8501

[34] Hamilton, D. and Jackson, M. (1998) Spiritual Development: Paths and Processes. Journal of Instructional Psychology, 25, 262-270.

[35] Miller, R. (1995/96) The Renewal of Education and Culture: A Multifaceted Task. Great Ideas in Education, 7, 130.

[36] Moore, T. (2006) The Spirituality in Leadership. Spirituality and Health: The Soull Body Connection, 9, 10-11.

[37] Maharshi, R. and Venkataramiah, M. (1972 \& 2001) Talks with Ramana Maharshi: On Realizing Abiding Peace and Happiness. 2nd Edition, Inner Directions, Carlsbad. http://www.goodreads.com

[38] Allington, R.L. (2002) What I've Learned about Effective Reading Instruction. Phi Delta Kappan, 83, 740-747. https://doi.org/10.1177/003172170208301007

[39] Hénard, F. and Roseveare, D. (2012) Fostering Quality Teaching in Higher Education: Policies and Practices. An IMHE Guide for Higher Education Institutions. 
7-11.

[40] Mitchell, R.D. (1998) World Class Teachers: When Top Teachers Earn National Board Certification, Schools- and Students-Reap the Benefits. The American School Board Journal, 185, 27-29.

[41] Carnegie Mellon University. Teaching Excellence \& Educational Innovation. http://www.cmu.edu

[42] Department of Education (DEpEd) (2001) Order 54.

[43] Lagman, R., Yoo, G., Levine, E., Donnell, K. and Lim, H. (2014 ) Leaving It to God: Religion, Spirituality and Filipina American Breast Cancer Survivors. Journal Religion Health, 53, 449-460. https://doi.org/10.1007/s10943-012-9648-Z

[44] Goh, R.B.H. (2005) Christianity in Southeast Asia. Institute of Southeast Asian Studies, Singapore. https://doi.org/10.1355/9789812307033

[45] David, E.J.R. and Okazaki, S. (2006) Colonial Mentality: A Review and Recommendation for Filipino American Psychology. Cultural Diversity and Ethnic Minority Psychology, 2, 1-16. https://doi.org/10.1037/1099-9809.12.1.1

[46] Gonzalez, J.J. (2009) Filipino American Faith in Action: Immigration, Religion, and Civic Engagement. New York University Press, New York. https://doi.org/10.18574/nyu/9780814731963.001.0001

[47] Nadal, K.L. (2009) Filipino American Psychology: A Handbook of Theory, Research, and Clinical Practice. Author House, Bloomington.

[48] Targ, E.F. and Levine, E.G. (2002) The Efficacy of a Mind-Body-Spirit Group for Women with Breast Cancer: A Randomized Controlled Trial. General Hospital Psychiatry, 24, 238-248. https://doi.org/10.1016/S0163-8343(02)00191-3

[49] Mt. 28:19-20. The Holy Bible-The New Kings Version.

[50] Walker, T. (2016) Does Teaching Experience Matter: Let's Count the Ways. http://www.neatoday.org

[51] Kini, T. and Podilsky, A. (2016) Does Teaching Experience Increase Teacher Effectiveness? A Review of the Research. @learningpolicyinstitute.org.

[52] Benner, P. (1984 \& 1986) From Novice to Expert. American Journal of Nursing, 82, 402-407. https://doi.org/10.1097/00000446-198282030-00004

[53] Riding the Beast. Properties of Number 8. http://www.ridingthebeast.com

[54] Pullen, R. and Mathias, T. (2010) Fostering Therapeutic Nurse-Patient Relationship. Nursing Made Incredibly Easy, 8, 4.

https://doi.org/10.1097/01.NME.0000371036.87494.11 